International Journal of Environment, Agriculture and Biotechnology
Vol-6, Issue-4; Jul-Aug, 2021
J Journal Home Page Available: https://ijeab.com/
Journal DOI: $10.22161 /$ ijeab

Article

Peer-Reviewed Journal

\title{
Physicochemical property of rubber nursery plants biochar and its effect on the growth of Hevea brasiliensis seedlings
}

\author{
Xianhong Chen*, Qing Chen, Jun Wang
}

Rubber Research Institute, Chinese Academy of Tropical Agricultural Sciences, Danzhou, Hainan 571737, China

* Corresponding author

Received: 06 Jun 2021; Received in revised form: 25 Jun 2021; Accepted: 04 Jul 2021; Available online: 12 Jul 2021

(C)2021 The Author(s). Published by Infogain Publication. This is an open access article under the CC BY license (https://creativecommons.org/licenses/by/4.0/).

\begin{abstract}
In order to improve the reutilization rate of rubber seedling-stock shoots waste and minimize the burden on the ecological environment, we investigated physicochemical property of rubber nursery plants biochar and its effect on growth of Hevea seedlings. The results showed that sand bed seedlings biochar had the smaller stem diameter, the more $N$ and $P$ content but the less $K$ content and soluble sugar, in comparison with polybag budding biochar and polybag seedling biochar. Stem of polybag budding plants as nutrient medium had less $\mathrm{pH}$ value and more electrical conductivity than that of seedling plants biochar. Medium in $N$ and $\mathrm{K}$ nutrient were negatively correlated $(P<0.05)$ with plant height, stem diameter and leaf whorls of rubber seedlings. Taken together, stem biochar as nutrient medium was better than leaf tissue powder as nutrient medium for the growth of rubber seedlings.
\end{abstract}

Keywords-Hevea brasiliensis, Rubber nursery plants, Biochar, Physicochemical property, Growth.

\section{INTRODUCTION}

Rubber buddings in polybags nursery with surface soils are the main maintenance of nursery. The seedling stocks are green-budded at six to eight months old. The stocks of successful buddings are cut-back. Rubber nursery production for polybag-buddings normally consume 600 ton surface soil and accompany with 756.8 ton seedlingstock shoots every year in our rubber nursery, and 34,400 ton seedling-stock shoots during the 13th Five-Year (20162020) Plan Period in rubber planting areas of China. Those seedling-stock shoots were burn or thrown away in the past, which has caused a burden on the ecological environment. In order to improve the reutilization rate of agricultural waste and minimize the burden on the ecological environment, crop production biochar has been introduced since last two decades (Laird., 2008). Biochar, a carbon rich source application ameliorates drought stress by increasing the plant growth, biomass, nutrient uptake and improves gaseous exchange in drought stress.
Application of biochar reduces drought stress by increasing water holding capacity of soil through modification of soil physio-chemical properties that in turn increases water availability to plants and also enhances mineral uptake and regulation of stomatal conductance. Biochar mediates the retention of moisture, nutrients, inhibits harmful bacteria, absorbs heavy metals, pesticides, prevents soil erosion, increases soil $\mathrm{pH}$, improves cationic exchange and boosts soil fertility (Mansoor et al., 2021). Biochar addition can significantly improve the growth and physiology of Phragmites australis, increase soil organic carbon content and decrease soil $\mathrm{NH}^{+}-\mathrm{N}$ content due to the N uptake by Phragmites australis (Liang et al., 2021). The combination of biochar and chemical fertilizer dissolved organic carbon and shaped soil bacterial community by $\mathrm{pH}$, total nitrogen and available potassium for the improvements of tea growth and low nutrients acidic tea orchard soil (Yang et al, 2021). Wood carbonization increased soil $\mathrm{pH}$, soil exchangeable $\mathrm{P}$ and 


\section{K (Chidumayo,1994).}

For the research reported herein, we investigated physicochemical property of rubber nursery plants biochar and its effect on growth of Hevea seedlings, and further explore the feasibility of using it as a seedling-raising substrate.

\section{MATERIAL AND METHODS}

\section{Rubber Nursery Plants Biochar}

The experiment was conducted from October 2017 to November 2020 in the nursery base of natural rubber of Rubber Research Institute of Chinese Academy of Tropical Agricultural Sciences $\left(19^{\circ} 49^{\prime} 22^{\prime \prime} \mathrm{N}, 109^{\circ} 49^{\prime} 27^{\prime \prime} \mathrm{E}\right)$, Danzhou City, Hainan Province, China. Sand bed seedlings, polybag seedlings (rootstock-plants), polybag buddings (scion-plants) were harvested, with leaves sundried and with stem girth measured, and pyrolyzed at $500^{\circ}$ Cfor 96 hours (Table1), and then ground, respectively. Each treatment contained 50 plants, three replications.

\section{Analytical Methods}

The plants biochar volume weight, total porosity, aeration porosity, water-holding porosity and gas-water ratio were measured according to Liu (2001). The plants biochar EC value was determined with a Electrical Conductivity Meter (DDS-307A, Shanghai, China) according to by mixing plants biochar and water to a mass ratio of 1:5. The plants biochar $\mathrm{pH}$ was determined with a $\mathrm{pH}$ Meter (Mettler Toledo, SevenCompact S210, Zuirich, Switzerland) by mixing plants biochar and water to a mass ratio of 1:25. The plants biochar total nitrogen content was measured by the alkali-diffusion method, the plants biochar total phosphorus was determined with the molybdenum antimony resistance spectrophotometric method, and the plants biochar total potassium was estimated with a flame photometer (Jingke-F6410, Shaihai Yidian Analytical Instrument Co., Shanghai, China). Soluble Sugar content were measured according to $\mathrm{Li}$ (2000).

\section{Rubber Seedlings Growth Experiment}

Rubber seedlings with one leaf whorl at leaf-expansion stage were transplanted into root-container with $6 \mathrm{~cm}$ upper diameter, $2 \mathrm{~cm}$ lower diameter and $37 \mathrm{~cm}$ high. The nursery medium were rubber leaves tissue powder and stem biochar (Table1), respectively. At 2-3 mature leaf whorls stage of rubber seedling, plant height, stem diameter, and leaf whorls were measured, respectively.

\section{Statistical Analyses}

Statistical analyses were performed with Data Processing System (DPS) statistical software package version 16.5 using one-way ANOVA followed by the Duncan's Multiple Range Test (SSR) to evaluate significant difference among seedlings from different rubber plants biochar as nursery medium and seedlings growth parameters. All data were shown in the mean $\pm \mathrm{SD}$ of three biological replicates (each replication contained 50 plants).

\section{RESULT AND DISCUSSION}

\section{Characteristic of rubber nursery plants biochar}

As shown in Table1, dried leaves and stem pyrolyzed at $500^{\circ} \mathrm{C}$ for 96 hours were ground into different colors. Stem girth of stem3 (polybag seedling stem) was $92.10 \%$ more $(\mathrm{P}<0.01)$ and $401 \%$ more $(\mathrm{P}<0.01)$ than that of stem 2 (polybag budding stem) and stem1 (sand bed seedling stem), respectively. Stem girth of stem2 (polybag budding stem) was $161 \%$ more $(\mathrm{P}<0.01)$ than stem1 (sand bed seedling stem).

Table1 Characteristic of rubber nursery plants biochar

\begin{tabular}{|c|c|c|c|c|}
\hline Samples & Leaves & Stem1 & Stem2 & Stem3 \\
\hline Stem girth(mm) & - & $15.47 \pm 2.01 \mathrm{cC}$ & $40.36 \pm 5.15 \mathrm{bB}$ & $77.53 \pm 8.89 \mathrm{aA}$ \\
\hline \multirow{2}{*}{ Dried samples } & & & & \\
& & & & \\
\end{tabular}


Notes: Leaves, dried leaves. Stem1-3, stem pyrolyzed at $500^{\circ} \mathrm{C}$ for 96 hours. Stem1, sand bed seedling stem. Stem2, polybag budding stem. Stem3, polybag seedling stem. Data are means and SD, n=3.

Nutrient content of rubber nursery plants biochar As shown in Table2, $\mathrm{N}$ content of leaf1, was $22.69 \%$ more $(\mathrm{P}<0.01)$ and $19.18 \%$ more $(\mathrm{P}<0.01)$ than that of leaf 2 and leaf3, respectively. $\mathrm{N}$ content of stem 1 was $155 \%$ more $(\mathrm{P}<0.01)$ and $286 \%$ more $(\mathrm{P}<0.01)$ than that of stem 2 and stem3, respectively. There were no significant difference in $\mathrm{N}$ content between leaf 2 and leaf 3 , between stem 2 and stem3, respectively. $\mathrm{P}$ content of leaf1, was $75 \%$ more $(\mathrm{P}<0.01)$ than that of leaf2. Leaf1 and leaf3 gave no significant difference in $\mathrm{P}$ content. $\mathrm{P}$ content of stem 1 was $200 \%$ more $(\mathrm{P}<0.01)$ and $300 \%$ more $(\mathrm{P}<0.01)$ than that of stem 2 and stem 3 , respectively. While $\mathrm{P}$ content of stem2 was $33.33 \%$ more $(\mathrm{P}<0.05)$ than that of stem 3 . K content of leaf1, was $16.19 \%$ less $(\mathrm{P}<0.01)$ and $22.12 \%$ less $(\mathrm{P}<0.01)$ than that of leaf2 and leaf3, respectively. $\mathrm{K}$ content of leaf 2 was $7.08 \%$ less $(\mathrm{P}<0.01)$ than that of leaf 3. $\mathrm{K}$ content of stem 1 was $22.39 \%$ more $(\mathrm{P}<0.01)$ and $78.26 \%$ more $(\mathrm{P}<0.01)$ than that of stem 2 and stem 3 , respectively. $\mathrm{K}$ content of stem 2 was $45.65 \%$ less $(\mathrm{P}<0.01)$ than that of stem3. Soluble sugar content of leaf1 was $46.73 \%$ less $(\mathrm{P}<0.01)$ and $36.85 \%$ less $(\mathrm{P}<0.01)$ than that of leaf 2 and leaf3, respectively. There were no significant difference in soluble sugar content between leaf 2 and leaf 3 , among stem 1 , stem 2 and stem 3 , respectively. $\mathrm{C} / \mathrm{N}$ ratio of stem1 was $45.28 \%$ less $(\mathrm{P}<0.01)$ and $64.33 \%$ less $(\mathrm{P}<0.01)$ than that of stem 2 and stem 3 , respectively. $\mathrm{C} / \mathrm{N}$ ratio of stem 2 was $34.82 \%$ less $(\mathrm{P}<0.01)$ than that of stem 3 . These results showed that leaves had more nutrients than stem, seedling plants had more nutrients than budding plants, and the nutrient of sand bed seedlings had more $\mathrm{N}$ than polybag seedling. It is necessary that the reuse of rubber nursery wastes in rubber nursery is an appropriate method for environment management and nutrients provider to raise the rubber nursery seedlings and budding plants.

Table2 Nutrient content of rubber nursery plants biochar

\begin{tabular}{|c|l|c|c|c|c|c|}
\hline Parameters & \multicolumn{1}{|c|}{ Leaf1 } & \multicolumn{1}{|c|}{ Leaf 2} & Leaf 3 & Stem1 & Stem2 & Stem3 \\
\hline $\mathrm{N} \%$ & $2.92 \pm 0.19 \mathrm{aA}$ & $2.38 \pm 0.04 \mathrm{bB}$ & $2.45 \pm 0.15 \mathrm{bB}$ & $1.43 \pm 0.1 \mathrm{cC}$ & $0.56 \pm 0.06 \mathrm{dD}$ & $0.37 \pm 0.03 \mathrm{dD}$ \\
\hline $\mathrm{P} \%$ & $0.21 \pm 0.01 \mathrm{bAB}$ & $0.12 \pm 0.01 \mathrm{cC}$ & $0.2 \pm 0.01 \mathrm{bB}$ & $0.24 \pm 0.02 \mathrm{aA}$ & $0.08 \pm 0 \mathrm{dD}$ & $0.06 \pm 0 \mathrm{eD}$ \\
\hline $\mathrm{K} \%$ & $0.88 \pm 0.02 \mathrm{cC}$ & $1.05 \pm 0.02 \mathrm{bB}$ & $1.13 \pm 0.01 \mathrm{aA}$ & $0.82 \pm 0.06 \mathrm{dC}$ & $0.67 \pm 0.01 \mathrm{eD}$ & $0.46 \pm 0.02 \mathrm{fE}$ \\
\hline $\begin{array}{c}\text { Soluble sugar } \\
\text { content(mg.g } \\
-1\end{array}$ & $144.29 \pm 12.39 \mathrm{aA}$ & $98.34 \pm 6.82 \mathrm{bB}$ & $105.44 \pm 2.71 \mathrm{bB}$ & $27.74 \pm 0.97 \mathrm{cC}$ & $19.9 \pm 0.95 \mathrm{cC}$ & $20.02 \pm 1.37 \mathrm{cC}$ \\
\hline $\begin{array}{c}\text { C/N ratio } \\
\text { K }\end{array}$ & $\begin{array}{l}49.65 \pm 6.06 \mathrm{abA} \\
\mathrm{B}\end{array}$ & $\begin{array}{l}41.41 \pm 2.93 \mathrm{bcB} \\
\mathrm{C}\end{array}$ & $\begin{array}{l}43.18 \pm 3.84 \mathrm{bcAB} \\
\mathrm{C}\end{array}$ & $\begin{array}{l}19.47 \pm 2.01 \mathrm{~d} \\
\mathrm{D}\end{array}$ & $\begin{array}{l}35.58 \pm 4.46 \mathrm{c} \\
\mathrm{C}\end{array}$ & $\begin{array}{l}54.59 \pm 6.51 \mathrm{a} \\
\mathrm{A}\end{array}$ \\
\hline
\end{tabular}

Notes: Leaf1, dried leaves of Stem1, Leaf 2, dried leaves of Stem2, Leaf 3, dried leaves of Stem3. Stem1-3, stem pyrolyzed at $500^{\circ} \mathrm{C}$ for 96 hours. Stem1, sand bed seedling stem. Stem2, polybag budding stem. Stem3, polybag seedling stem. Data are means and SD, n=3. Lowercase and uppercase indicate significant difference at 0.05 and 0.01 levels, respectively.

Physicochemical property of rubber nursery plants biochar as nutrient medium As shown in Table3, volume weight of leaf3 was $58.97 \%$ more $(p<0.01)$ and $58.97 \%$ more $(\mathrm{p}<0.01)$ than that of leaf1 and leaf2, respectively. There were no significant difference in volume weight between leaf1 and leaf2, among stem1, stem 2 and stem3, respectively. Total porosity, aeration porosity, waterholding porosity and gas-water ratio gave no significant difference among leaves and stem. There were no significant difference in $\mathrm{pH}$ value among leaf1, leaf2 and leaf3, among stem1, stem 2 and stem3, respectively. However, stem 1 and stem 2 had less $\mathrm{pH}$ value than leaves at 0.05 and 0.01 level, respectively. Electrical conductivity of leaf1 was $59.69 \%$ more and $56.22 \%$ than that of leaf 2 and leaf3, respectively. Electrical conductivity of leaf 2 and leaf3 had no significant difference. Electrical conductivity of stem 1 was $48.35 \%$ more and $80.33 \%$ more than that of stem 2 and stem3, respectively. Electrical conductivity of stem 2 and stem 3 had no significant difference. The results showed that stem of budding plants as nutrient medium had less $\mathrm{pH}$ value and more electrical conductivity than that of seedling plants. Physio-chemical analysis (N, P, K, $\mathrm{pH}$, EC) were best in the growing media comprising biochar + peat moss + leaf compost for flower production 
(Altaf et al, 2021), which might indicate that different plants have various nutrient medium with biochar.

Table3 Physicochemical property of rubber nursery plants biochar as nutrient medium

\begin{tabular}{|c|c|c|c|c|c|c|}
\hline Parameters & Leaf1 & Leaf 2 & Leaf 3 & Stem1 & Stem2 & Stem3 \\
\hline $\begin{array}{l}\text { Volume } \\
\text { Weight } \\
\left(\mathrm{g} / \mathrm{cm}^{3}\right)\end{array}$ & $\begin{array}{c}0.39 \pm 0.02 \mathrm{c} \\
\mathrm{B}\end{array}$ & $0.39 \pm 0.05 \mathrm{cB}$ & $0.62 \pm 0.07 \mathrm{aA}$ & $0.55 \pm 0.13 \mathrm{abAB}$ & $\begin{array}{c}0.49 \pm 0.01 \mathrm{bcA} \\
\text { B }\end{array}$ & $0.44 \pm 0 \mathrm{bcB}$ \\
\hline $\begin{array}{c}\text { Total } \\
\text { porosity }(\% \\
\text { ) }\end{array}$ & $\begin{array}{c}7.93 \pm 0.02 \mathrm{a} \\
\mathrm{A}\end{array}$ & $7.93 \pm 0.07 \mathrm{aA}$ & $8 \pm 0.01 \mathrm{aA}$ & $7.99 \pm 0.02 \mathrm{aA}$ & $7.93 \pm 0.04 \mathrm{aA}$ & $7.96 \pm 0.02 \mathrm{aA}$ \\
\hline $\begin{array}{c}\text { Aeration } \\
\text { porosity } \%\end{array}$ & $\begin{array}{c}7.48 \pm 0.18 \mathrm{a} \\
\text { A }\end{array}$ & $7.82 \pm 0.07 \mathrm{aA}$ & $7.82 \pm 0.57 \mathrm{aA}$ & $7.99 \pm 0.32 \mathrm{aA}$ & $7.61 \pm 0.35 \mathrm{aA}$ & $8.08 \pm 0.37 \mathrm{aA}$ \\
\hline $\begin{array}{c}\text { Water- } \\
\text { holding } \\
\text { porosity } \%\end{array}$ & $\begin{array}{c}6.81 \pm 0.14 \mathrm{a} \\
\mathrm{A}\end{array}$ & $6.45 \pm 0.09 \mathrm{aA}$ & $6.09 \pm 0.55 \mathrm{aA}$ & $6.26 \pm 0.28 \mathrm{aA}$ & $6.53 \pm 0.27 \mathrm{aA}$ & $6.09 \pm 0.73 \mathrm{aA}$ \\
\hline $\begin{array}{c}\text { Gas-water } \\
\text { Ratio }\end{array}$ & $1.1 \pm \mathrm{aA}$ & $1.21 \pm \mathrm{aA}$ & $1.3 \pm \mathrm{aA}$ & $1.28 \pm \mathrm{aA}$ & $1.17 \pm \mathrm{aA}$ & $1.34 \pm \mathrm{aA}$ \\
\hline $\mathrm{pH}$ value & $\begin{array}{c}5.55 \pm 0.02 \mathrm{ab} \\
\mathrm{A}\end{array}$ & $5.56 \pm 0.3 \mathrm{abA}$ & $5.63 \pm 0.08 \mathrm{aA}$ & $5.12 \pm 0.02 \mathrm{cAB}$ & $4.94 \pm 0.02 \mathrm{cB}$ & $\begin{array}{c}5.21 \pm 0.38 \mathrm{bcA} \\
\text { B }\end{array}$ \\
\hline $\begin{array}{c}\text { Electrical } \\
\text { conductivi } \\
\text { ty }\end{array}$ & $\begin{array}{c}1342 \pm 77.9 \mathrm{a} \\
\mathrm{A}\end{array}$ & $\begin{array}{c}840.36 \pm 178.08 b \mathrm{bc} \\
\text { BC }\end{array}$ & $\begin{array}{c}859.04 \pm 132.65 b c \\
\text { BC }\end{array}$ & $\begin{array}{c}633.56 \pm 174.83 \mathrm{~cd} \\
\text { BC }\end{array}$ & $\begin{array}{c}939.8 \pm 60.11 b \\
\text { B }\end{array}$ & $\begin{array}{c}521.16 \pm 95.63 \\
\mathrm{dC}\end{array}$ \\
\hline
\end{tabular}

Notes: Leaf1, dried leaves of Stem1, Leaf 2, dried leaves of Stem2, Leaf 3, dried leaves of Stem3. Stem1-3, stem pyrolyzed at $500^{\circ} \mathrm{C}$ for 96 hours. Stem1, sand bed seedling stem. Stem2, polybag budding stem. Stem3, polybag seedling stem. Data are means and $\mathrm{SD}, \mathrm{n}=3$. Lowercase and uppercase indicate significant difference at 0.05 and 0.01 levels, respectively.

Effect of rubber nursery plants biochar as nutrient medium on rubber seedling growth As shown in Table4, plant height of rubber seedlings grown in stem 1 as nutrient medium was $10.83 \%$ lower $(\mathrm{p}<0.01)$ and $13.93 \%$ lower $(\mathrm{p}<0.01)$ than that of stem 2 and stem 3 , respectively. There were no significant difference in plant height between stem 2 and stem3, among leaves as nutrient medium, respectively. Stem diameter of rubber seedlings grown in leaf3 as nutrient medium was $7.09 \%$ smaller $(\mathrm{p}<0.01)$ and $4.83 \%$ smaller $(\mathrm{p}<0.05)$ than that of leaf 2 and leaf1, respectively. There were no significant difference in stem diameter between leaf1 and leaf2, among stem as nutrient medium, respectively. Leaf whorls of rubber seedlings grown in leaf2 as nutrient medium was $10.68 \%$ less $(p<0.05)$ and $15.73 \%$ less $(p<0.01)$ than that of leaf 1 and leaf3, respectively. Leaf whorls of rubber seedlings grown in stem 1 as nutrient medium was $15.84 \%$ less $(p<0.01)$ and $15 \%$ less $(p<0.01)$ than that of stem 2 and stem3, respectively. There were no significant difference in leaf whorls between leaf1 and leaf3, between stem 2 and stem 3 as nutrient medium, respectively. Stem diameter of rubber seedlings grown in leaf3 as nutrient medium was
$4.84 \%$ lower $(\mathrm{p}<0.05)$ and $7.09 \%$ smaller $(\mathrm{p}<0.01)$ than that of leaf1 and leaf2, respectively. There were no significant difference in stem diameter between leaf1 and leaf2, among stem as nutrient medium, respectively. Leaf whorls of rubber seedlings grown in leaf 2 as nutrient medium was $10.68 \%$ less $(\mathrm{p}<0.05)$ and $15.73 \%$ lower $(p<0.01)$ than that of leaf1 and leaf3, respectively. Leaf whorls of rubber seedlings grown in stem 1 as nutrient medium was $15.84 \%$ less $(\mathrm{p}<0.01)$ and $15 \%$ lower $(\mathrm{p}<0.01)$ than that of stem 2 and stem 3 , respectively. There were no significant difference in leaf whorls between leaf1 and leaf3, between stem 2 and stem 3 as nutrient medium, respectively. These results suggested that stem as nutrient medium was better than leaf as nutrient medium for the growth of rubber seedlings. Considering the cost of river sand, availability and germination capacity, leached coir pith is considered as an ideal seed germination medium for rubber (Joseph and Jessy, 2005), while the tomato seedlings grew on the pure wheat straw decomposed matter showed the worst performance(Yang et al., 2020), which showed that different plants had their own suitable medium. 
Table4 Effect of rubber nursery plants biochar as nutrient medium on rubber seedling growth

\begin{tabular}{|c|c|c|c|}
\hline Medium composition & Plant height $(\mathrm{cm})$ & Stem diameter $(\mathrm{mm})$ & Leaf whorls \\
\hline Leaf1 & $35.11 \pm 4.22 \mathrm{cBC}$ & $3.72 \pm 0.38 \mathrm{bBC}$ & $2.34 \pm 0.48 \mathrm{bBC}$ \\
\hline Leaf2 & $35.57 \pm 3.69 \mathrm{cBC}$ & $3.81 \pm 0.26 \mathrm{bAB}$ & $2.09 \pm 0.29 \mathrm{cC}$ \\
\hline Leaf & $34.35 \pm 4.14 \mathrm{cC}$ & $3.54 \pm 0.31 \mathrm{cC}$ & $2.48 \pm 0.51 \mathrm{bB}$ \\
\hline Stem1 & $37.87 \pm 5.66 \mathrm{bB}$ & $3.86 \pm 0.44 \mathrm{abAB}$ & $2.55 \pm 0.51 \mathrm{bB}$ \\
\hline Stem2 & $42.47 \pm 4.91 \mathrm{aA}$ & $4.01 \pm 0.31 \mathrm{aA}$ & $3.03 \pm 0.45 \mathrm{aA}$ \\
\hline Stem3 & $44 \pm 3.95 \mathrm{aA}$ & $4.03 \pm 0.27 \mathrm{aA}$ & $3 \pm 0.27 \mathrm{aA}$ \\
\hline
\end{tabular}

Notes: Leaf1, dried leaves of Stem1, Leaf 2, dried leaves of Stem2, Leaf 3, dried leaves of Stem3. Stem1-3, stem pyrolyzed at $500^{\circ} \mathrm{C}$ for 96 hours. Stem1, sand bed seedling stem. Stem2, polybag budding stem. Stem3, polybag seedling stem. Data are means and $\mathrm{SD}, \mathrm{n}=3$. Lowercase and uppercase indicate significant difference at 0.05 and 0.01 levels, respectively.

\section{Correlation analysis of rubber nursery plants biochar} as nutrient medium on rubber seedling growth As shown in Table 5, plant height was significantly positive correlation with stem diameter $(\mathrm{p}=0.0118)$, leaf whorls $(\mathrm{p}=0.0162)$ and stem girth of rubber nursery plants as medium nutrient $(p=0.0245)$, respectively. However, plant height was significantly negative correlation with $\mathrm{N}$ $(p=0.0035), K(p=0.0224)$, soluble sugar $(p=0.0247)$ content and $\mathrm{pH}$ value $(\mathrm{p}=0.0174)$ of rubber nursery plants biochar as nutrient medium, respectively. Stem diameter was significantly negative correlation with $\mathrm{N}(\mathrm{p}=0.0298)$, $\mathrm{K}(\mathrm{p}=0.0259)$ content and $\mathrm{pH}$ value $(\mathrm{p}=0.0349)$ of rubber nursery plants biochar as nutrient medium, respectively. Leaf whorls were significantly negative correlation with $\mathrm{N}(\mathrm{p}=0.0158), \mathrm{K}(\mathrm{p}=0.037)$ content and stem girth $(p=0.0208)$ of rubber nursery plants biochar as nutrient medium, respectively. $\mathrm{N}$ content of rubber nursery plants biochar as nutrient medium was significantly positive correlation with $\mathrm{K}(\mathrm{p}=0.0321)$, soluble sugar $(\mathrm{p}=0.0021)$ content and $\mathrm{pH}$ value $(\mathrm{p}=$ $0.0246)$, but significantly negative correlation with stem girth $(p=0.0122)$, respectively. $K$ content of rubber nursery plants biochar as nutrient medium was significantly negative correlation with stem girth $(\mathrm{p}=$ 0.0069). Soluble sugar content of rubber nursery plants biochar as nutrient medium was significantly positive correlation with $\mathrm{pH}$ value $(\mathrm{p}=0.0154)$. These results showed that high nutrients of rubber nursery medium was not good for the growth of rubber seedlings due to the existence of seed nutrient at the initial growth stage.

\section{CONCLUSION}

In summary, sand bed seedlings as rubber nursery plants biochar had the smaller stem diameter, the more $\mathrm{N}$ and $\mathrm{P}$ content but the less $\mathrm{K}$ content and soluble sugar, in comparison with polybag budding and polybag seedling. Stem of polybag budding plants as nutrient medium had less $\mathrm{pH}$ value and more electrical conductivity than that of seedling plants. Stem as nutrient medium was better than leaf as nutrient medium for the growth of rubber seedlings.

Table5 Correlation analysis of rubber nursery plants biochar as nutrient medium on rubber seedling growth

\begin{tabular}{|c|c|c|c|c|c|c|c|c|c|}
\hline Factors & $\begin{array}{c}\text { Plant } \\
\text { height }\end{array}$ & $\begin{array}{c}\text { Stem } \\
\text { diameter }\end{array}$ & $\begin{array}{c}\text { Leaf } \\
\text { whorls }\end{array}$ & N\% & P\% & K\% & $\begin{array}{c}\text { Soluble } \\
\text { sugar }\end{array}$ & $\begin{array}{c}\text { SH } \\
\text { girth }\end{array}$ \\
\hline Plant height & & 0.0118 & 0.0162 & 0.0035 & 0.1053 & 0.0224 & 0.0247 & 0.0174 & 0.0245 \\
\hline $\begin{array}{c}\text { Stem } \\
\text { diameter }\end{array}$ & 0.91 & & 0.1487 & 0.0298 & 0.1305 & 0.0259 & 0.0588 & 0.0349 & 0.0622 \\
\hline Leaf whorls & 0.8943 & 0.666 & & 0.0158 & 0.2632 & 0.037 & 0.0557 & 0.0737 & 0.0208 \\
\hline N\% & -0.9515 & -0.8556 & -0.8956 & & 0.1507 & 0.0321 & 0.0021 & 0.0246 & 0.0122 \\
\hline P\% & -0.7219 & -0.6884 & -0.5452 & 0.6636 & & 0.2279 & 0.3101 & 0.4649 & 0.1026 \\
\hline K\% & -0.8751 & -0.8655 & -0.8384 & 0.85 & 0.5797 & & 0.0987 & 0.0899 & 0.0069 \\
\hline soluble sugar & -0.8687 & -0.7948 & -0.8006 & 0.9627 & 0.5022 & 0.7312 & & 0.0154 & 0.0645 \\
\hline
\end{tabular}




\begin{tabular}{|c|c|c|c|c|c|c|c|c|c|}
\hline $\mathrm{pH}$ & -0.8903 & -0.8433 & -0.7693 & 0.869 & 0.3742 & 0.744 & 0.8969 & & 0.1619 \\
\hline Stem girth & 0.8695 & 0.7888 & 0.8797 & $\begin{array}{c}- \\
0\end{array}$ & $\begin{array}{c}- \\
-\end{array}$ & $\begin{array}{c}- \\
0.932\end{array}$ & -0.7848 & $\begin{array}{c}- \\
0.6505\end{array}$ & \\
\hline
\end{tabular}

Notes: Correlation coefficients on the lower left, p-value on the upper right.

\section{ACKNOWLEDGEMENTS}

This work was supported by the earmarked fund for China Agriculture Research System (CARS-34-YZ4).

\section{REFERENCES}

[1] Laird A. David. 2008. The Charcoal Vision: A Win-WinWin Scenario for Simultaneously Producing Bioenergy, Permanently Sequestering Carbon, while Improving Soil and Water Quality. Agronomy Journal, 100: 178-81.

[2] Mansoor Sheikh; Kour Navneet; Manhas Sweeta; Zahid Sheikh; Wani Owais Ali; Sharma Vikas; Wijaya Leonard; Alyemeni Mohammed Nasser; Alsahli Abdulaziz Abdullah; ElSerehy Hamed A; Paray Bilal Ahmad; Ahmad Parvaiz. 2021, Biochar as a tool for effective management of drought and heavy metal toxicity. Chemosphere, 271: 129458 .

[3] Liang Jinfeng, Li Qianwei, Gao Junqin, Feng Jiuge, Zhang Xiaoya, Hao Yijing, Yu Feihai. 2021. Biochar-compost addition benefits Phragmites australis growth and soil property in coastal wetlands. Science of The Total Environment,769: 145166.

[4] Yang Wenhao; Li Changjuan; Wang Shanshan; Zhou Biqing; Mao Yanling; Rensing Christopher; Xing Shihe. 2021. Influence of biochar and biochar-based fertilizer on yield, quality of tea and microbial community in an acid tea orchard soil, Applied Soil Ecology, 166, 104005.

[5] Chidumayo E.N. 1994. Effects of wood carbonization on soil and initial development of seedlings in miombo woodland, Zambia. Forest Ecology and Management, 70(13): $353-357$.

[6] Liu Shizhe. 2000. Modern practical soilless culture technique. Agriculture Press of China, Beijing, pp150-153.

[7] Li Hesheng. 2000. Principles and techniques of plant physiological biochemical experiment. Higher Education Press, Beijing, pp 195-197.

[8] Khadija Altaf, Adnan Younis, Yasir Ramzan \& Fahad Ramzan. 2021. Effect of composition of agricultural wastes and biochar as a growing media on the growth of potted Stock (Matthiola incana) and Geranium (Pelargonium spp), Journal of Plant Nutrition, 44:7, 919-930.

[9] Joseph Phebe and Jessy M.D. 2005.Coir pith: A cost effective for rubber seed (Hevea Brasiliensis). Rubber Science. 28(3): 237-246.

[10] Yang Fan, Mi Guoquan, Tang Yanling, Shi Yanyan, Niu Lili, Zhao Xiushan, Shi Xuanjie, Ma Kai, Cheng Yutong.
2020. Effect of wheat straw composite substrate on the growth and development of tomato seedlings,. China Cucurbits and Vegetables. 33(4): 50-55. 